\title{
Biodiversity of Antimicrobial-Producing Actinomycetes Strains Isolated from Dry Dipterocarp Forest Soil in Northeast Thailand
}

\author{
Panjamaphon Chanthasena ${ }^{1}$, Nawarat Nantapong ${ }^{2 *}$. \\ ${ }^{1}$ School of Pharmacology, Institute of Science, Suranaree University of Technology, Thailand. ${ }^{2}$ School of \\ Microbiology, Institute of Science, Suranaree University of Technology, Thailand.
}

\begin{abstract}
The increasing use of antibiotics has led to the development of drug-resistant microorganisms. The emergence of resistant strains has compromised the treatment and control of infectious diseases. As a result, the search and development of a novel class of antibiotic drugs are required. Actinomycetes have been recognized as a richest source of secondary metabolites including antibiotics. The aim of this study was to investigate the diversity of antibioticproducing soil Actinomycetes from dry dipterocarp forest in Northeast of Thailand. The soil from this area has been known for its poor in nutrients and highly acidic with $\mathrm{pH}$ values around 4.5. In such a harsh condition, soil-inhabiting Actinomycetes elevate their protective mechanisms by inducing the production of antimicrobials and other defense compounds. Therefore, dry dipterocarp forest could be served as a potential source for the screening of the novel antimicrobial drugs.

Twelve antibiotic-producing strains isolated from soil in Suranaree University of Technology produce antimicrobial agents which are active against wide range of test pathogens including methicillin-resistant Staphylococcus aureus (MRSA). Based on 16S rRNA gene analysis, these strains are close affiliated with the genus Streptomyces (11 isolates) and Nonomuraea (1 isolate). Most of soil isolates show narrow antimicrobial spectrum activity against Gram-positive bacteria. Two isolates, PJ36 and PJ95, exhibit broad antimicrobial spectrum against Gram-positive bacteria, Gramnegative bacteria and yeasts. Phylogenetic tree analysis of $16 \mathrm{~S}$ rDNA reveals that isolates PJ33, PJ36, PJ43, PJ51, PJ75, PJ76, PJ77, PJ85, PJ88 and PJ95 strains are not cluster with others strain of Streptomyces. They represent a distinct phyletic line which might be suggested the novel strains.

This study was the first attempted to isolate antibiotic-producing Actinomycetes from dry dipterocarp forest soil in Northeast Thailand. Most of soil isolates (8 strains) obtained from this study were active against methicillin-resistant Staphylococcus aureus (MRSA). These isolates could be used for the development of new drugs to combat antibiotic resistances.
\end{abstract}

Key words: Soil bacteria, Antibiotics, Actinomycetes, Streptomyces

*Authors for correspondence: nawarat@sut.ac.th 


\section{INTRODUCTION}

According to the World Health Organization, the widespread use of antibiotics in medicine has led to the resistant of many pathogens (Parungao et al. 2007). Serious infections caused by antibiotic resistant bacteria have become a major global healthcare problem in the $21^{\text {st }}$ century (Alanis 2005; Sharma et al. 2011; Kannabiran and Rajan 2013). The most common resistant bacterial strains causing important community acquired infections are methicillin-resistant Staphylococcus aureus (MRSA), vancomycin-resistant Staphylococcus aureus (VRSA), vancomycin-resistant Enterococcus (VRE) and extended spectrum $\beta$ lactamase producing bacteria (ESBL) (Sharma et al. 2011). MRSA has been identified as an important nosocomial infection causing organism (Kumar and Rao 2012). This resistant bacterial strain has become a worldwide concern since it is highly prevalent and potentially cause death. It is capable of developing the new clones to resist to almost all currently available antibiotics except vancomycin and teicoplanin (Witte 1999; Isnansetyo and Kamei 2003). Nowadays, vancomycin-intermediate Staphylococcus aureus (VISA) and vancomycinresistant Staphylococcus aureus (VRSA) have been reported in several countries (Isnansetyo and Kamei 2003; David and Daum 2010). Thus, there is an urgent needed to the search of new antibiotic agents, particularly against drug-resistant strains.

Soil microorganisms are the major resource for isolation of several important products such as antimicrobial drugs, anticancer drugs, herbicides and insecticides (Sanglier et al. 1993; Jeya et al. 2013). Among soil-inhabiting microbes, Actinomycetes have been recognized as antibiotic producers. Three quarter of all known antibiotics such as tetracycline, vancomycin and erythromycin are produced by Actinomycetes (Varghese et al. 2012). Actinomycetes are widely distributed groups in soil environments which play a major role in the recycling of organic matters and nutritional materials (Velayudham and Murugan 2012). They are filamentous Gram-positive bacteria belonging to the phylum Actinobacteria. They represent one of the largest taxonomic units currently recognized within the domain Bacteria (Ventura et al. 2007). Approximately $80 \%$ of the world's antibiotics are derived from Actinomycetes, mostly from the genera Streptomyces and Micromonospora
(Arifuzzaman et al. 2010; George et al. 2011; Ravi et al. 2015). However, in the past two decades there has been a decline in the discovery of new lead compounds from Streptomyces and other terrestrial Actinomycetes (Mincer et al. 2002; Valan et al. 2012). It has been reported that only $1-3 \%$ of all known antimicrobial compounds produced by genus Streptomyces has been identified and isolated, therefore; there is a vast majority of antibiotics left to be discovered (Baltz 2005; Shetty et al. 2014). The classification and identification of Actinomycetes can be performed by numerous taxonomic methods such as ribosomal protein analysis (Ochi 1995), fatty acid composition analysis (Zhang et al. 2007) and 16S rRNA gene sequence analysis (Ramos et al. 1997; Prasad et al. 2013; Radhakrishnan et al. 2013). However, the determination of 16S rRNA gene has been found to be an appropriate method for investigating phylogeny of microorganisms due to its slow rates of evolution (Song et al. 2001; Liu 2011).

Thailand is located in the humid climatic area where a variety of tropical ecosystems are found. The diversity of organisms in Thai soil has been studied for decades, however; biodiversity of soil microorganisms in many area of Thailand including Nakhon Ratchasima province remains uninvestigated and documented. The present study was focused on the investigation of phylogenetic diversity of the culturable Actinobacteria from dry dipterocarp forest soil based on 16S rRNA gene analysis. The study of phylogenetic has been shown to be a powerful tool in undestanding biological diversity and evolutionary relationships among the organisms (Nithya et al. 2012).

\section{MATERIAL AND METHODS}

\section{Study area and sample collection}

The study site was located at the forest area in Suranaree University of Technology, Nakhon Ratchasima province, Thailand. The latitude and longitude of the study area is 14.8729 and 102.0237, respectively. Approximately $100 \mathrm{~g}$ of soil samples were randomly taken from the forest area throughout Suranaree University of Technology, Thailand (Ng and Amsaveni 2012). The samples were collected at a depth of $10-15 \mathrm{~cm}$ from the upper surface of soil using sterile technique and immediately taken to the laboratory and stored at $4^{\circ} \mathrm{C}$ until study (Sweetline 2012). The 
collected soil samples were analyzed for physiochemical parameter including soil $\mathrm{pH}$, moisture content and nutrient contents (Nitrogen, Phosphorous, Potassium). The moisture content of soil was determined by analog soil moisture meter (Sinokit, China). The soil pH and nutrient contents were measured using Quick soil test (Hanna instruments, UK).

\section{Media and culture condition}

Starch casein agar (SCA): (g/l: soluble starch 10; casein 0.3 ; potassium nitrate 2; sodium chloride 2; dipotassium hydrogen phosphate 2 ; magnesium sulphate 0.05 ; calcium carbonate 0.02 ; ferrous sulphate 0.01 ; agar $15 ; \mathrm{pH}$ 7.2) (Kuster and Williams 1964) was used for the isolation of Actinomycetes. The cultivation temperature of Actinomycetes was $28^{\circ} \mathrm{C}$. To determine the ability of antimicrobial activity of soil isolates, Mueller Hinton Agar (MHA) (Hi-media, India) was used. The incubation temperature for antimicrobial activity test were $30^{\circ} \mathrm{C}$ or $37^{\circ} \mathrm{C}$ depending on the strains of test pathogens.

\section{Test pathogens}

The pathogenic strains used for the screening of antimicrobial activity were obtained from Department of Medical Sciences Thailand (DMST) and Thailand Institute of Scientific and Technological Research (TISTR). They were methicillin-resistant Staphylococcus aureus DMST20654 (MRSA), Staphylococcus aureus TISTR1466, Staphylococcus epidermidis TISTR518, Bacillus subtilis TISTR008, Bacillus cereus TISTR687, Escherichia coli TISTR780, Enterobacter aerogenes TISTR1540, Pseudomonas aeruginosa TISTR781, Serratia marcescens TISTR1354, Proteus mirabilis TISTR100, Candida albicans TISTR5779, Candida tropicalis TISTR5174 and Saccharomyces cerevisiae TISTR5049.

\section{Isolation of Actinomycetes}

Isolation of Actinomycetes was performed by serial dilution and plating technique using SCA medium (Basavaraj et al. 2010). One gram of soil sample was suspended in Erlenmeyer flask containing 99 $\mathrm{ml}$ sterile water and incubated at room temperature without shaking for $30 \mathrm{~min}$. The soil suspension was serially diluted and spread on SCA plate. The plates were incubated at $28^{\circ} \mathrm{C}$ for 5 days. After incubation, the suspected Actinomycetes colonies were selected and kept in the presence of glycerol $(15 \% \mathrm{v} / \mathrm{v})$ at $-80^{\circ} \mathrm{C}$ for further study.

\section{Determination of antimicrobial activity of soil isolates using perpendicular streak plate}

Soil isolates were screened for their antimicrobial activity by perpendicular streak method (Egorov 1987). The isolate strains were inoculated on MHA plate by single streaking at the center of a petridish. The plates were incubated at $28^{\circ} \mathrm{C}$ for 5 days in order to allow the organisms to produce antimicrobial substances and release to an agar medium. The plates were then seeded with test pathogens by streaking perpendicular to the line of soil isolate colonies. The zone of inhibition against test pathogens of each isolate was observed after 24-48 $\mathrm{h}$ of incubation.

\section{S rRNA gene sequencing}

Genomic DNA of bacterial strains was isolated from cell grown in $5 \mathrm{ml}$ Mueller Hinton Broth (MHB) at $28^{\circ} \mathrm{C}$ for 3 days. The cell cultures were centrifuged at 13,000 rpm for $5 \mathrm{~min}$ and the cell pellets were used for DNA extraction. Five to ten milligram of cell pellets were mixed with $180 \mu$ of $50 \mathrm{mM} \mathrm{NaOH}$. The cell suspensions were incubated at $95^{\circ} \mathrm{C}$ for $10 \mathrm{~min}$ followed by adding $20 \mu \mathrm{l}$ of $1 \mathrm{M}$ Tris- $\mathrm{HCl}$ ( $\mathrm{pH}$ 8.0). Cells were pelleted by centrifugation at $13,000 \mathrm{rpm}$ for $5 \mathrm{~min}$. The supernatants were used as DNA template for PCR amplification of 16S rRNA gene. The 16S rRNA gene was amplified by PCR with specific universal primers, 243F (5'-GGATGAGCCGCGGCCTA3') and A3R (5'-CCAGCCCCACCTTCGAC-3') (Monciardini et al. 2002). Amplification was performed in a thermal cycler (BIORAD, USA) according to the following conditions: initial denaturation $95^{\circ} \mathrm{C}$ for 5 min followed by 30 cycles of denaturation at $95^{\circ} \mathrm{C}$ for $60 \mathrm{~s}$, annealing at $55^{\circ} \mathrm{C}$ for $60 \mathrm{~s}$, extension at $72^{\circ} \mathrm{C}$ for $60 \mathrm{~s}$ and a final extension at $72^{\circ} \mathrm{C}$ for $7 \mathrm{~min}$. The amplified fragments were purified from $0.8 \%$ agarose gel by using NucleoSpin ${ }^{\circledR}$ Gel and PCR clean-up kit (MACHEREY-NAGEL, Germany). The purified products were submitted for sequencing at Macrogen, Korea.

\section{Construction of phylogenetic tree}

16S rRNA gene sequence of the isolates were compared against the GenBank DNA database using BLAST program. The sequences were aligned with closely-related species by using 
CLUSTAL W (Thompson et al. 1994). The phylogenetic tree was constructed by neighborjoining method (Saitou and Nei 1987) using Molecular Evolutionary Genetics Analysis software version 6.0 (MEGA 6) (Tamura et al. 2013). The confidence level of each branch $(1,000$ replications) was tested by bootstrap analysis (Felsenstein 1985).

\section{RESULTS AND DISCUSSION}

Total of 37 soil samples were collected from forest area around Suranaree University of Technology, Nakhon Ratchasima, Thailand $\left(14.8729^{\circ} \mathrm{N}\right.$, $102.0237^{\circ}$ E), during January 2012 to February 2013 (Fig. 1). Soil samples were randomly taken and aseptically transferred by sterile polyethylene bags to the laboratory.

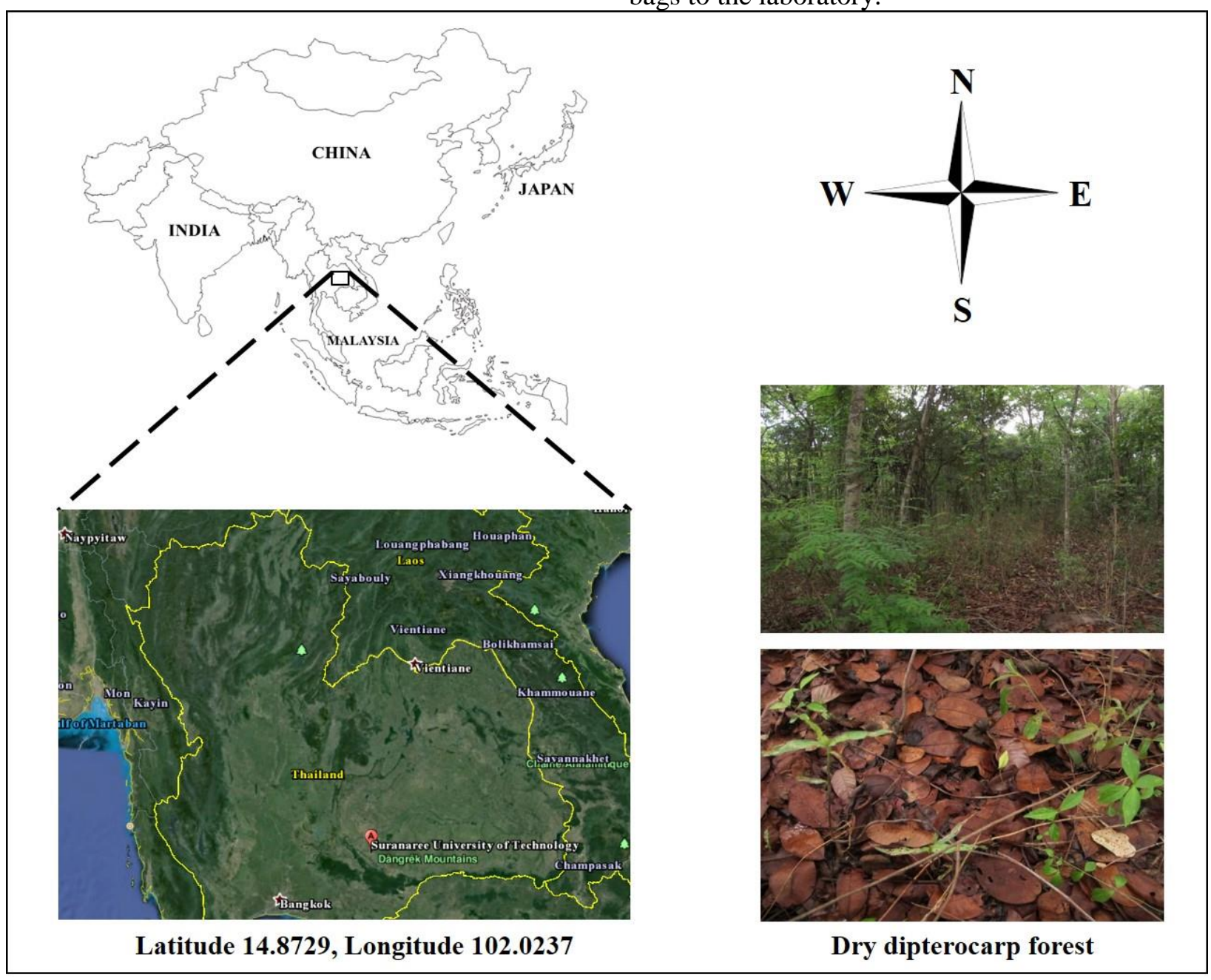

Figure 1 - Map of the sampling site. Suranaree University of Technology is situated in Nakhon Ratchasima province, Northeastern region of Thailand. Dry dipterocarp forests are found throughout this area. The latitude of Suranaree University of Technology is 14.8729 and longitude is 102.0237 .

Isolation of Actinomycetes was done by serial dilution and plating technique using SCA medium. Several colonies were appeared on SCA after incubation at $28^{\circ} \mathrm{C}$ for 5 days. Colonies having characteristic features such as powdery or waxy appearance with convex, concave of flat surface and color ranging from white, gray to pinkish and yellowish were isolated and screened for their antimicrobial activity. One hundred-twenty three isolates were obtained and given the name as PJ1 to PJ123. All 123 isolates were screened for their antimicrobial activity against Staphylococcus aureus DMST20654 (MRSA), Staphylococcus aureus TISTR1466, Staphylococcus epidermidis TISTR518, Bacillus subtilis TISTR008, Bacillus cereus TISTR687, Escherichia coli TISTR780, Enterobacter aerogenes TISTR1540, Pseudomonas aeruginosa TISTR781, Serratia 
marcescens TISTR1354, Proteus mirabilis TISTR100, Candida albicans TISTR5779, Candida tropicalis TISTR5174 and Saccharomyces cerevisiae TISTR5049 by perpendicular streak method. The antimicrobial activity was observed from twelve isolates named PJ33, PJ36, PJ43, PJ51, PJ75, PJ76, PJ77, PJ85, PJ88, PJ90, PJ95 and PJ107 (Fig. 2).
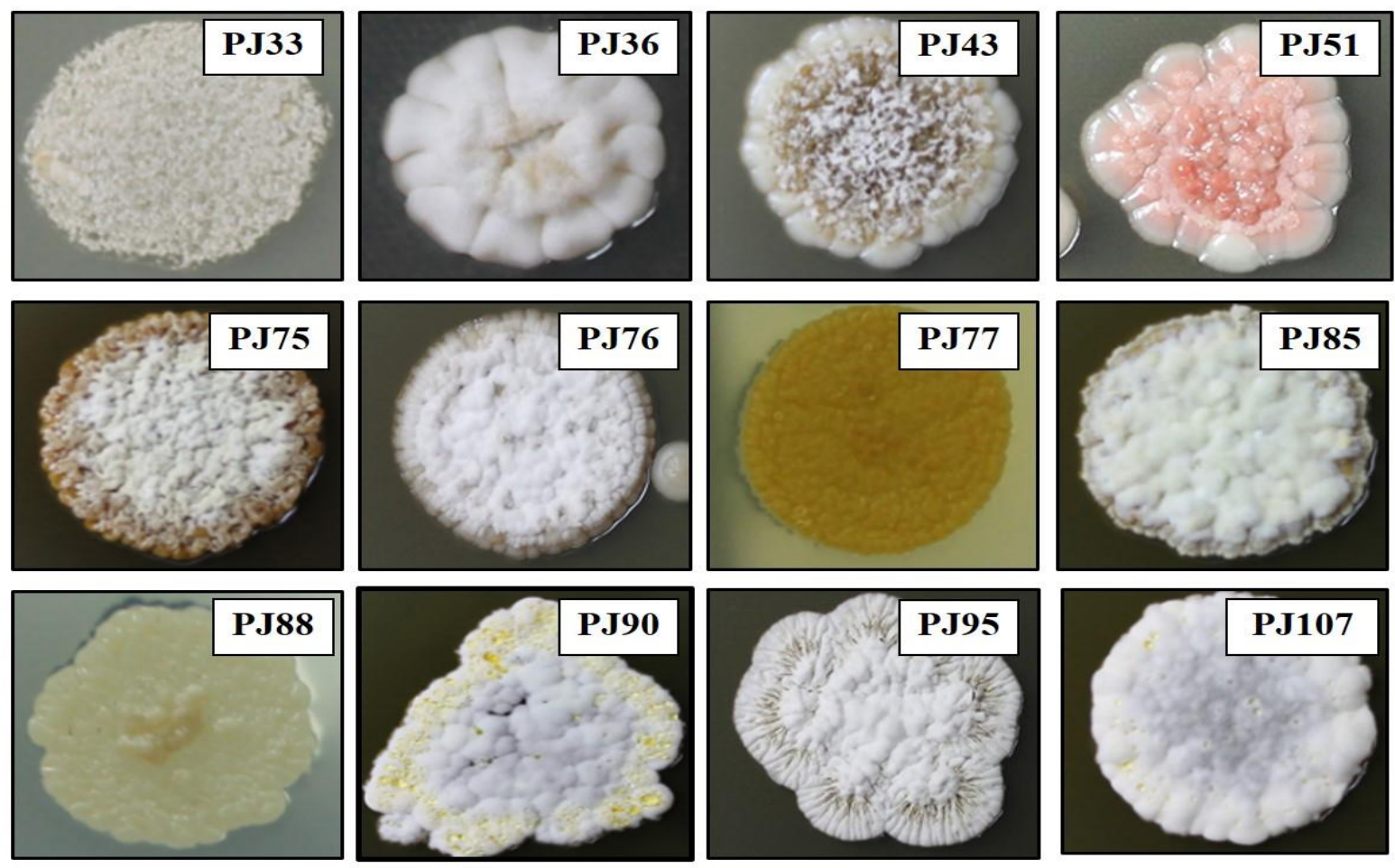

Figure 2 - Colony morphology of twelve antimicrobial-producing soil isolates. The bacterial cell was grown on SCA plate and incubated at $28^{\circ} \mathrm{C}$ for 5 days.

Twelve antimicrobial-producing strains could be divided into three groups based on their spectrum of activity (Table 1). Group I are isolates PJ33 and PJ77 that show antibacterial activity against only Gram-positive bacteria. Group II consist of soil isolates PJ43, PJ51, PJ75, PJ76, PJ85, PJ88, PJ90 and $\mathrm{PJ} 107$ which are capable of producing antimicrobial agents against Gram-positive bacteria and yeasts. Group III include PJ36 and PJ95 that exhibit broad spectrum antimicrobial activity against Gram-positive bacteria, Gram-negative bacteria and yeasts. There are eight isolates, PJ43, PJ75, PJ77, PJ85, PJ88, PJ90, PJ95 and PJ107, that have been found to be effective against methicillinresistant Staphylococcus aureus DMST20654 (MRSA). These results indicate that most of isolates are having narrow spectrum antimicrobial activity against Gram-positive bacteria. The antibacterial activity of these isolates against Grampositive bacteria is observed more often than that against Gram-negative bacteria. This frequency of activity against Gram-positive bacteria of soil Actinomycetes is similar to those reported by Basilio, Kokare, Oskay, Valli and Deshmukh (Basilio et al. 2003; Kokare et al. 2004; Oskay et al. 2005; Valli et al. 2012 and Deshmukh and Vidhale 2015). 
Table 1. Antimicrobial activity of antibiotic-producing soil isolates against test pathogens

\section{Isolates Pathogenic strains}

\begin{tabular}{|c|c|c|c|c|c|c|c|c|c|c|c|c|c|}
\hline & 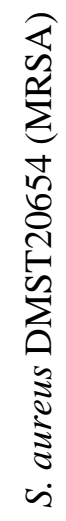 & 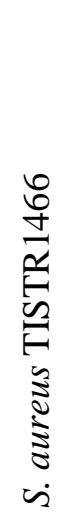 & 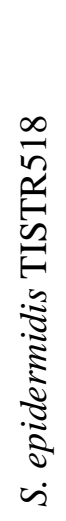 & 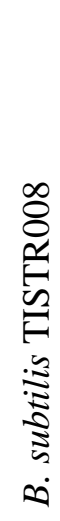 & 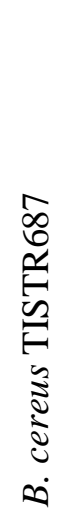 & 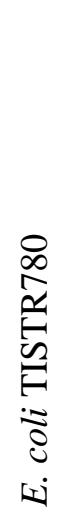 & 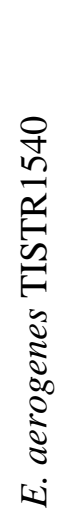 & 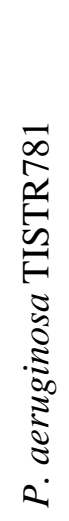 & 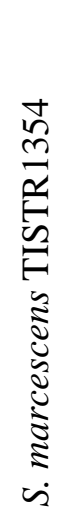 & 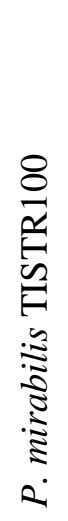 & 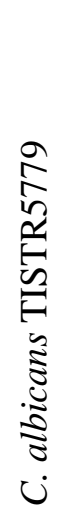 & 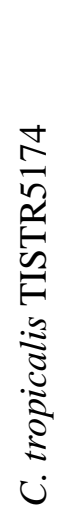 & 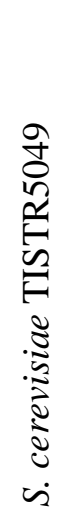 \\
\hline PJ33 & - & - & - & - & + & - & - & - & - & - & - & - & - \\
\hline PJ36 & - & + & + & + & + & + & + & - & + & + & + & + & + \\
\hline PJ43 & + & + & + & + & + & - & - & - & - & - & + & - & + \\
\hline PJ51 & - & - & + & - & + & - & - & - & - & - & - & - & + \\
\hline PJ75 & + & + & + & + & + & - & - & - & - & - & + & - & + \\
\hline PJ76 & - & - & - & - & + & - & - & - & - & - & + & + & + \\
\hline PJ77 & + & + & - & + & + & - & - & - & - & - & - & - & - \\
\hline PJ85 & + & + & + & + & + & - & - & - & - & - & + & - & + \\
\hline PJ88 & + & + & + & + & + & - & - & - & - & - & + & - & + \\
\hline PJ90 & + & + & + & + & + & - & - & - & - & - & + & - & + \\
\hline PJ95 & + & + & + & + & + & + & - & - & + & + & + & + & + \\
\hline PJ107 & + & + & + & + & + & - & - & - & - & - & + & - & + \\
\hline
\end{tabular}

(+) inhibition; (-) no effect

The identification of 12 antimicrobial-producing soil isolates was based on $16 \mathrm{~S}$ rRNA gene sequencing. The $16 \mathrm{~S}$ rRNA gene was amplified by using universal primers, $243 \mathrm{~F}$ and A3R 
(Monciardini et al. 2002). The amplified fragments were compared with nucleotide sequences from NCBI GenBank database. The $16 \mathrm{~S}$ rDNA sequences of all 12 antimicrobial-producing strains were submitted to GenBank database. The GenBank accession numbers of these isolates are provided in Table 2.

Table 2. Phylogenetic affiliation and GenBank accession numbers of antimicrobial-producing isolates

\begin{tabular}{llll}
\hline Isolates & Identification (nearest match) & $\begin{array}{l}\text { Similarity } \\
(\boldsymbol{\%})\end{array}$ & $\begin{array}{l}\text { Accession } \\
\text { numbers }\end{array}$ \\
\hline PJ33 & Streptomyces alboniger DSM40043 & 98 & KT795537 \\
\hline PJ36 & Streptomyces rimosus subsp. paramomycinus NBRC15454 & 99 & KT795542 \\
\hline PJ43 & Streptomyces thermocarboxydovorans DSM44295 & 97 & KT795532 \\
\hline PJ51 & Nonomuraea bangladeshensis $13651 \mathrm{M}$ & 94 & KT795543 \\
\hline PJ75 & Streptomyces griseoruber MTCC8121 CKM5 & 98 & KT795536 \\
\hline PJ76 & Streptomyces iakyrus NBRC13401 & 99 & KT795533 \\
\hline PJ77 & Streptomyces bingchengensis HBUM174849 & 98 & KT795534 \\
\hline PJ85 & Streptomyces triostinicus CKM7 & 99 & KT795538 \\
\hline PJ88 & Streptomyces gilvosporeus ATCC13326 & 97 & KT795535 \\
\hline PJ90 & Streptomyces triostinicus CKM7 & 99 & KT795539 \\
\hline PJ95 & Streptomyces luteosporeus NBRC14657 & 99 & KT795540 \\
\hline PJ107 & Streptomyces triostinicus CKM7 & 99 & KT795541 \\
\hline
\end{tabular}

The phylogenetic relationship between soil isolates and known actinobacteria was determined on the basis of their 16S rRNA gene sequence. The tree was constructed by neighbor-joining method with bootstrap 1,000 replicates (Fig. 3). 


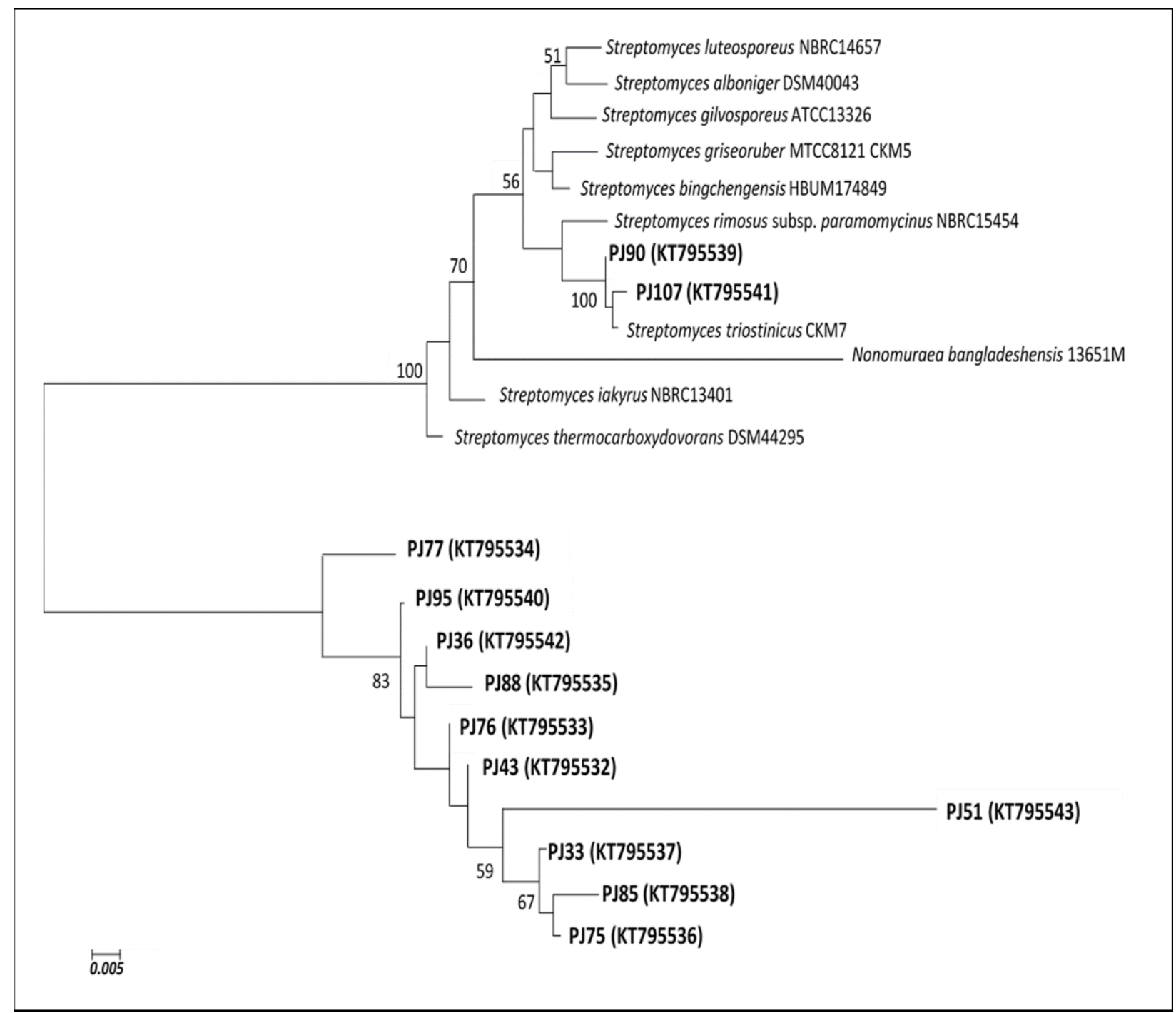

Figure 3 - Phylogenetic tree showing evolutionary relationship of twelve antimicrobial-producing soil isolates and their related taxa. The $16 \mathrm{~S}$ rRNA gene sequences were aligned by using CLUSTAL W. The neighbor-joining phylogenetic tree was generated by using the Molecular Evolutionary Genetics Analysis software version 6.0 (MEGA 6 ). Numbers at the nodes indicate levels of bootstrap support based on 1,000 resampling, only value $\geq 50 \%$ are shown. The scale bar indicates 0.005 substitutions per nucleotide position.

The result showed that PJ90 and PJ107 were closely related with Streptomyces triostinicus CKM7. Hence, PJ90 and PJ107 might be classified as Streptomyces triostinicus. Other remaining isolates, PJ33, PJ36, PJ43, PJ51, PJ75, PJ76, PJ77, PJ85, PJ88 and PJ95, showed a distant relationship with recognized species from GenBank database. They could not be fitted into any known cluster as shown in Figure 3. It has been suggested by Goodfellow and Dickenson (1985) that organisms from natural habitats that do not from tight clusters with recognized reference strains could be assigned to a new taxa (Goodfellow and Dickinson 1985). Thus, PJ33, PJ36, PJ43, PJ51, PJ75, PJ76, PJ77, PJ85, PJ88 and PJ95, were unclassified. They were arranged in a separate group which possibly be represented the novel strains (Fig. 3).

In this study, we were able to isolate $S$. alboniger, $S$. rimosus, $S$. thermocarboxydovorans, $N$. bangladeshensis, S. griseoruber, S. iakyrus, $S$. bingchengensis, S. triostinicus, S. gilvosporeus and $S$. luteosporeus from Northeast soil of Thailand. Among them, there were only $S$. griseoruber and $S$. triostinicus that have been isolated from terrestrial soil in Thailand so far (Tantithanagorngul et al. 2011; Intra et al. 2011). The previous reports of $S$. griseoruber and $S$. triostinicus from Thai soil were included the study of antitumor and antifungal activities, respectively (Tantithanagorngul et al. 2011; Intra et al. 2011). To our best knowledge, this 
study constitutes the first antibacterial and antifungal properties of $S$. alboniger, $S$. rimosus, $S$. thermocarboxydovorans, $N$. bangladeshensis, $S$. iakyrus, $S$. bingchengensis, $S$. gilvosporeus and $S$. luteosporeus isolated from Thai soil.

Our results demonstrated that soil from dry dipterocarp forest in Suranaree University of Technology cantains a diverse group of antibioticproducing Actinomycetes strains. The physiological and chemical analysis of soil studied were also conducted. As expected, the results showed that forest soil in Suranaree University of Technology was dry, acidic (pH 5) and low in nutrients. These results are in good agreement with those mentioned earlier that Actinomycetes are able to survive and colonize under extreme soil habitats. Thus, a soil sample from dry dipterocarp forest in Suranaree University of Technology is proven to be a valuable source for the screening of antimicrobialproducing strains of Actinomycetes.

\section{CONCLUSION}

Results of this study indicate that dry dipterocarp forest in Suranaree University of Technology contain great biodiversity of antibiotic-producing Actinomycetes. The dominant genus found in this area is Streptomyces. They are active against wide range of test pathogens including MRSA. Thus, the study of these isolates could be further explored for the development of new antibiotic drugs to treat infectious diseases causing by pathogenic and drugresistant strains.

\section{ACKNOWLEDGEMENTS}

The authors wish to thank Suranaree University of Technology for research funding through plant genetic conservation project under the Royal initiative of her Royal highness princess Maha Chakri Sirindhorn-Suranaree University of Technology (RSPG-SUT).

\section{REFERENCES}

Alanis AJ. Resistance to antibiotics: are we in the postantibiotic era?, Arch Med Res. 2005; 36(6): 697-705.

Arifuzzaman M, Khatun M, Rahman H. Isolation and screening of actinomycetes from Sundarbans soil for antibacterial activity, Afr J Biotechnol. 2010; 9(29): 4615-4619.
Baltz R. Antibiotic discovery from actinomycetes: will a renaissance follow the decline and fall, SIM News. 2005; 55(5): 186-196.

Basavaraj K, Chandrashekhara S, Shamarez AM, Goudanavar PS, Manvi FV. Isolation and morphological characterization of antibiotic producing actinomycetes. T J Pharm Res. 2010; 9(3): 231-236.

Basilio A, Gonzalez I, Vicente M, Gorrochategui J, Cabello A, Gonzalez A, et al. Patterns of antimicrobial activities from soil actinomycetes isolated under different conditions of $\mathrm{pH}$ and salinity, $J$ Appl Microbiol. 2003; 95(4): 814-823.

David MZ, Daum RS. Community-associated methicillin-resistant Staphylococcus aureus: epidemiology and clinical consequences of an emerging epidemic, Clin Microbiol Rev. 2010; 23(3): 616-687.

Deshmukh AA, Vidhale NN. Characterization of novel antibacterial Actinomycetes strain N8 from saline soil of Vidarbha region, Int J Life Sci Biotechnol Pharma Res. 2015; 4(1): 22-25.

Egorov NS. Antibiotics, a scientific approach. Mir Publishers, Moscow. 1987: 60.

Felsenstein J. Confidence limits on phylogenies: an approach using the bootstrap, Evolution. 1985; 39(4): 783-791.

George M, George G, Hatha AM. Diversity and antibacterial activity of actinomycetes from wetland soil, South Pac J Nat Appl Sci. 2011; 28(1): 52-57.

Goodfellow M, Dickinson C. Delineation and description of microbial populations using numerical methods, Comput-assisted Bacterial syst. 1985; 165 225.

Intra B, Mungsuntisuk I, Nihira T, Igarashi Y, Panbangred W. Identification of actinomycetes from plant rhizospheric soils with inhibitory activity against Colletotrichum spp., the causative agent of anthracnose disease, BMC research notes. 2011; 4(1): 98-106.

Isnansetyo A, Kamei Y. MC21-A, a bactericidal antibiotic produced by a new marine bacterium, Pseudoalteromonas phenolica sp. nov. O-BC30T, against methicillin-resistant Staphylococcus aureus, Antimicrob Agents Ch. 2003; 47(2): 480-488.

Jeya K, Kiruthika K, Veerapagu M. Isolation of antibiotic producing Streptomyces sp. from soil of Perambalur district and a study on the antibacterial activity against clinical pathogens, Int J PharmTech Res. 2013; 5: 1207-1211.

Kannabiran K, Rajan MB. Antimicrobial activity of Streptomyces albofaciens against methicillin-resistant Staphylococcus aureus and vancomycin resistant Enterococcus multi-drug resistant species, Res J Pharm Biol Chem Sci. 2013; 4: 1248-1257.

Kokare C, Mahadik K, Kadam S, Chopade B. Isolation, characterization and antimicrobial activity of marine halophilic Actinopolyspora species AH1 from the west 
coast of India, Curr Sci Bangalore. 2004; 86(4): 593597.

Kumar SRS, Rao KVB. In-vitro antimicrobial activity of marine actinobacteria against multidrug resistance Staphylococcus aureus, Asian Pac J Trop Biomed. 2012; 2(10): 787-792.

Kuster E, Williams S. Selection of media for isolation of Streptomycetes, Nature. 1964; 202: 928-929.

Liu D. Molecular detection of human bacterial pathogens, Florida: CRC press; 2011.

Mincer TJ, Jensen PR, Kauffman CA, Fenical W. Widespread and persistent populations of a major new marine actinomycete taxon in ocean sediments, Appl Environ Microb. 2002; 68(10): 5005-5011.

Monciardini P, Sosil M, Cavaletti L, Chiocchini C, Donadio S. New PCR primers for the selective amplification of $16 \mathrm{~S}$ rDNA from different groups of actinomycetes, FEMS Microbiol Ecol. 2002; 42(3): 419-429.

$\mathrm{Ng} \mathrm{Z}$, Amsaveni S. Isolation, screening and characterization of antibiotic-producing actinomycetes from rhizosphere

region of different plants from a farm of Sungai Ramal Luar, Malaysia, J Adv Biomed Pathobiol Res. 2012; 2(3): 96-107.

Nithya B, Ponmurugan P, Fredimoses M. 16S rRNA phylogenetic analysis of actinomycetes isolated from Eastern Ghats and marine mangrove associated with antibacterial and anticancerous activities, J Niger Assoc Math Phys. 2012; 11(60): 12379-12388.

Ochi K. Phylogenetic analysis of mycolic acidcontaining wall-chemotype IV actinomycetes and allied taxa by partial sequencing of ribosomal protein AT-L30, Int J Syst Evol Microbiol. 1995; 45(4): 653660.

Oskay AM, Usame T, Cem A. Antibacterial activity of some actinomycetes isolated from farming soils of Turkey, Afr J Biotechnol. 2005; 3(9): 441-446.

Parungao MM, Maceda EBG, Villano MAF. Screening of antibiotic-producing actinomycetes from marine, brackish and terrestrial sediments of Samal Island, Philippines, J Res Sci Comput Eng. 2007; 4(3): 29-38.

Prasad P, Singh T, Bedi S, Kumari S. Molecular characterization and phylogenetic analysis of cellulase producing Streptomyces griseorubens (strain st-1) isolated from Indian soil, Jordan J Biol Sci. 2013; 6(3): 239-242.

Radhakrishnan M, Venugopal Gopikrishnan AS, Selvakumar N, Balagurunathan R. Characterization and phylogenetic analysis of antituberculous compound producing actinomycete strain D25 isolated from Thar Desert soil, Rajasthan, Bioinformation. 2013; 9(1): 18-22.

Ramos CP, Foster G, Collins MD. Phylogenetic analysis of the genus Actinomyces based on 16S rRNA gene sequences: Description of Arcanobacterium phocae sp. nov., Arcanobacterium bernardiae comb. nov., and
Arcanobacterium pyogenes comb. nov, Int J Syst Evol Microbiol. 1997; 47(1): 46-53.

Ravi RK, Vasantba J, Bhoomi M, Bonisha T, Bhumika C. Antibacterial potentials of Actinomycetes isolated from Gujarat, Int J Pharm Sci Rev Res. 2015; 30: 7883.

Saitou N, Nei M. The neighbor-joining method: a new method for reconstructing phylogenetic trees, $\mathrm{Mol} \mathrm{Biol}$ Evol. 1987; 4(4): 406-425.

Sanglier J, Haag H, Huck T, Fehr T. Novel bioactive compounds from actinomycetes: a short review (19881992), Res Microbiol. 1993; 144(8): 633-642.

Sharma D, Kaur T, Chadha B, Manhas RK. Antimicrobial activity of actinomycetes against multidrug resistant Staphylococcus aureus, Escherichia coli and various other pathogens, Trop J Pharm Research. 2011; 10(6): 801-808.

Shetty PR, Buddana SK, Tatipamula VB, Naga YVV, Ahmad J. Production of polypeptide antibiotic from Streptomyces parvulus and its antibacterial activity, Braz J Microbiol. 2014; 45(1): 303-312.

Song J, Weon H-Y, Yoon S-H, Park D-S, Go S-J, Suh JW. Phylogenetic diversity of thermophilic actinomycetes and Thermoactinomyces spp. isolated from mushroom composts in Korea based on 16S rRNA gene sequence analysis, FEMS Microbiol Lett. 2001; 202(1): 97-102.

Sweetline C, Usha R, Palaniswamy M. Antibacterial activity of actinomycetes from Pichavaram Mangrove of Tamil Nadu, Appl J Hygiene. 2012; 1(2): 15-18.

Tamura K, Stecher G, Peterson D, Filipski A, Kumar S. MEGA6: molecular evolutionary genetics analysis version 6.0, Mol Biol Evol. 2013; 30(12): 2725-2729.

Tantithanagorngul W, Sujitwanit A, Piluk J, Tolieng V, Petsom A, Sangvanich P, et al. Screening for brine shrimp larvicidal activity of Streptomyces isolated from soil and anti-tumor activity of the active isolates, Aust J Basic Appl Sci. 2011; 5(7): 15-22.

Thompson JD, Higgins DG, Gibson TJ. CLUSTAL W: improving the sensitivity of progressive multiple sequence alignment through sequence weighting, position-specific gap penalties and weight matrix choice, Nucleic Acids Res. 1994; 22(22): 4673-4680.

Valan AM, Ignacimuthu S, Agastian P. Actinomycetes from Western Ghats of Tamil Nadu with its antimicrobial properties, Asian Pac J Trop Biomed. 2012; 2(2): S830-S837.

Valli S, Suvathi SS, Aysha O, Nirmala P, Vinoth KP, Reena A. Antimicrobial potential of Actinomycetes species isolated from marine environment, Asian Pac J Tro Biomed. 2012; 2(6): 469-473.

Varghese R, Nishamol S, Suchithra R, Jyothy S, Hatha AM. Distribution and antibacterial activity of Actinomycetes from Shola soils of tropical Montane forest in Kerala, South India, J Environ. 2012; 1: 93 99.

Velayudham S, Murugan K. Diversity and antibacterial screening of actinomycetes from Javadi Hill forest 
soil, Tamilnadu, India, J Microbiol Res. 2012; 2(2): 41-46.

Ventura M, Canchaya C, Tauch A, Chandra G, Fitzgerald GF, Chater KF et al. Genomics of Actinobacteria: tracing the evolutionary history of an ancient phylum, Microbiol Mol Biol Rev. 2007; 71(3): 495-548.

Witte W. Antibiotic resistance in gram-positive bacteria: epidemiological aspects, J Antimicrob Chemoth. 1999; 44(1): 1-9.
Zhang Q-c, Wang G-h, Yao H-y. Phospholipid fatty acid patterns of microbial communities in paddy soil under different fertilizer treatments, J Environ Sci. 2007; 19(1): 55-59.

Received: November 03, 2015; Accepted: April 112016 